Volume 2 Nomor 1 November 2015 ISSN: 2407-7062 |e-ISSN: 2442-5435

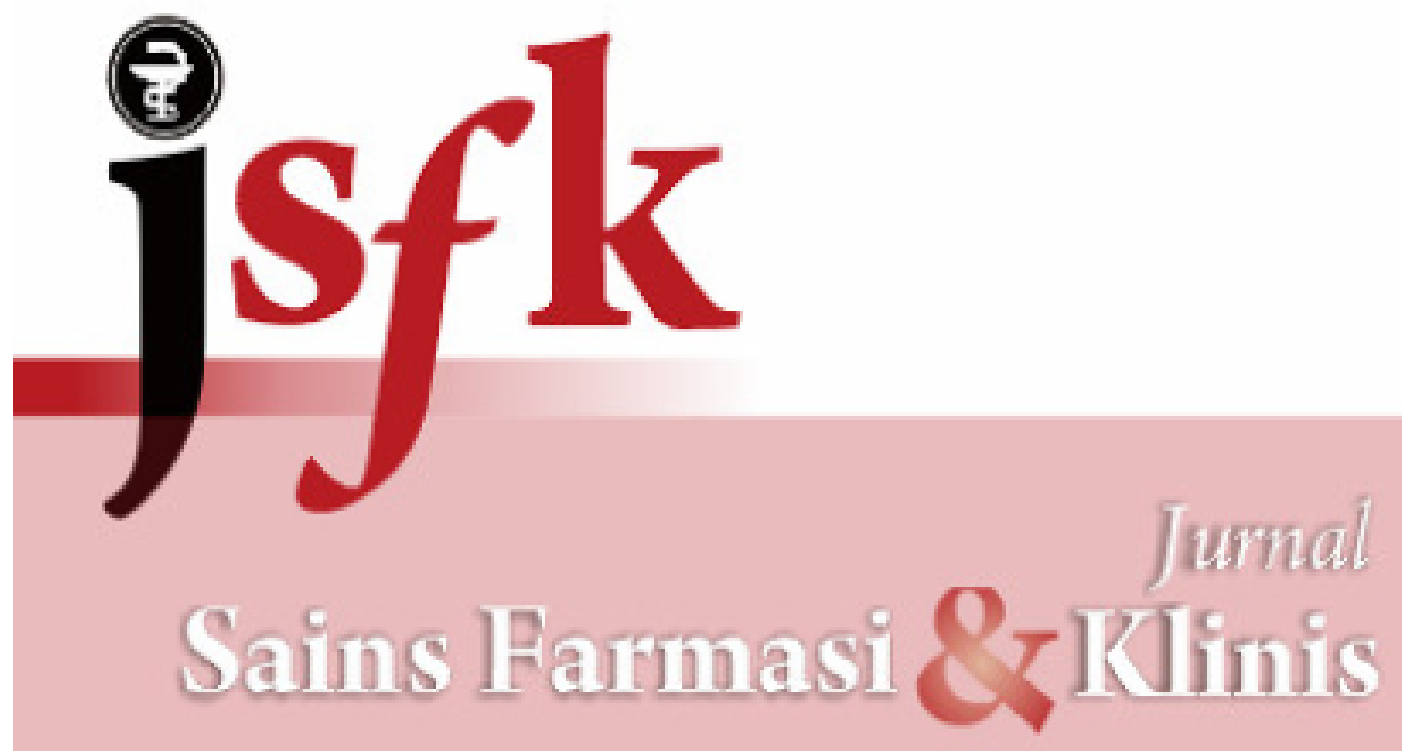

SEM don sipve hatosin MO dan dispors pedatno

Diterbitkan oleh:

the IKATAN AFOTIKER INDONISIA

GD IKATAN AFOTI

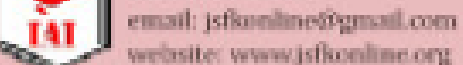

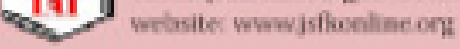




\section{Dewan Editorial}

\section{Editor in Chief}

Dr Erizal Zaini, Faculty of Pharmacy, Andalas University

\section{Managing Editor}

Yori Yuliandra, Fakultas Farmasi Universitas Andalas, Indonesia Ms Rahmi Yosmar, Fakultas Farmasi Universitas Andalas, Indonesia Ms Lili Fitriani, Fakultas Farmasi Universitas Andalas, Indonesia

\section{Editorial Board Members}

Dr Elfahmi Elfahmi, Sekolah Farmasi, Institut Teknologi Bandung, Indonesia

Dr Fatma Sri Wahyuni, Fakultas Farmasi Universitas Andalas, Indonesia

Prof Henny Lucida, Fakultas Farmasi Universitas Andalas, Indonesia

Dr Dwi Setyawan, Fakultas Farmasi Universitas Airlangga, Indonesia

Dr Khairunnisa Khairunnisa, Fakultas Farmasi Universitas Sumatera Utara, Indonesia

Dr Rika Yulia, Fakultas Farmasi Universitas Surabaya, Indonesia

Dr Dedy Almasdy, Fakultas Farmasi Universitas Andalas, Indonesia

Dr Yelly Oktavia Sari, Faculty of Pharmacy, Andalas University, Indonesia 


\section{Vol 2, № 1 (2015)}

Jurnal Sains Farmasi \& Klinis, Vol. 2 No. 1, November 2015

\section{Daftar Isi}

Kajian Kimia Dari Fraksi Etil Asetat Kulit Batang Kayu Pahit (Picrasma Javanica Bl.) PDF

3 Sri Hainil, Dayar Arbain, Deddi Prima Putra

[Dol] 10.25077/isfk.2.1.1-7.2015

Article view: 507 times

Validasi Penetapan Kadar Isolat Andrografolid dari Tanaman Sambiloto (Andrographis PDF

paniculata Nees) Menggunakan HPLC

3 Yandi Syukri, Agung Endro Nugroho, Ronny Martien, Endang Lukitaningsih

[dol> 10.25077/jsfk.2.1.8-14.2015

Article view: 1587 times

Kajian Toksisitas Serbuk Biji Mahoni terhadap Perkembangan Tingkah Laku, Histologi Hati

3. Hilmarni Hilmarni, Almahdy Almahdy, Helmi Arifin

ㅁo1》 10.25077/jsfk.2.1.15-21.2015

Article view: 543 times

Kajian Regimen Dosis Penggunaan Obat Asma pada Pasien Pediatri Rawat Inap di Bangsal

85. Rahmi Yosmar, Meri Andani, Helmi Arifin

Uolis 10.25077/jsfk.2.1.22-29.2015

Article view: 1983 times

Karakterisasi Fisikokimia Sistem Biner Siprofloksasin HCI - PEG 4000

30 Resva Meinisasti, Auzal Halim, Erizal Zaini

toid 10.25077/isfk.2.1.30-35.2015

Article view: 563 times

Efek Ekstrak Etanol Kulit Batang Sirsak Terhadap Penurunan Kadar Gula Darah dan Kolesterol

30 Dian Ayu Juwita, Husni Muchtar, Dolly Martho

바이 10.25077/jsfk.2.1.36-39.2015

Article view: 798 times 
Dampak Karakteristik Sosiodemografi dan Tingkat Kepatuhan Terapi Antihipertensi Terhadap

3. Maryorie Rosa, Armenia Armenia, Dedy Almasoly

ㅂoi》 10.25077/isfk.2.1.40-46.2015

Article view: 514 times

Gambaran Tenaga Kefarmasian Dalam Memberikan Informasi Kepada Pelaku Swamedikasi di

33 Septi Muharni, Fina Aryani, Maysharah Mizanni

[dol] 10.25077//5fk.2.1.47-53.2015

Article view: 976 times

Uji Toksisitas Subkronis Ekstrak Etanol Tali Putri (Cassytha filiformis L.) Terhadap Fungsi

3. Yori Yuliandra, Armenia Armenia, Annisa Nur Salasa, Friardi Ismed

G0i3 10.25077/j5fk.2.1.54-59.2015

Article view: 907 times

Pembangan dan Validasi Metode Kromatografi Lapis TipisDensitometri untuk Analisis

3. Fithriani Armin, Bita Revira, Adek Zomrud Adnon

[01] 10.25077/jsfk.2.1.60-65.2015

Article view: 1814 times

Senyawa Antioksidan Ekstrak Metanol Glycine max (L.) Merr Varietas Detam 1 Hasil Estraksi

3. Rika Yulia, Ivon Sindu Wijaya

dol》 10.25077/isfk.2.1.66-73.2015

Article view: 396 times

3. Tiara Adzakiyah, Indrawati Lipoeto, Nila Kasuma

dol》 10.25077/jsfk.2.1.74-77.2015

Article view: 861 times 
Studi Pendahuluan Profil Penggunaan Obat dan Kepatuhan terhadap Pengobatan pada Pasien Lupus di Komunitas

3. Sylvi Irowoti, Adji Proyitno, Angel Angel, Rosoti Herma Safitri

dois 10.25077/isfk.2.1.78-83.2015

Article view: 553 times

Pengaruh Pemberian Layanan Kefarmasian pada Penderita Pneumonia Komunitas Rawat

PDF(ENGLISH) Inap: A Small Randomized Single Blind Study

Bobby Presley, 1. Setiabudi, Lestiono Lestiono, Ediyono Ediyono

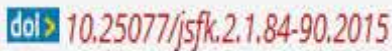

Article view: 354 times

Persepsi dan Kecenderungan Keterlibatan Apoteker di Apotek pada Proses Rekonsiliasi Obat

Eko Setiawan, Sylvi Irawati, Bobby Presley, Susilo Ari Wardhani

[0old 10.25077/jsfk.2.1.91-98.2015

Article view: 563 times

Pengaruh Pemberian Sari Wortel (Daucus carota L.) terhadap Tukak Lambung Pada Tikus

3. Suhotri Suhatri, Rusdi Rusdi, Emi Sugesti

dois 10.25077/sjfk.2.1.99-103.2015

Article view: 642 times

Evaluasi Penggunaan Obat Antidiabetik Pada Pasien Diabetes Melitus Tipe-2 di Suatu Rumah

Dedy Almasdy, Dita Permata Sari, Suhatri Suhatri, Deswinar Darwin, Nina Kurniasih

dois 10.25077/isfk.2.1.104-110.2015

Article view: 1477 times 


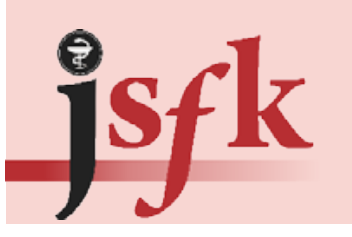

Jurnal Sains Farmasi \& Klinis (p-ISSN: 2407-7062 | e-ISSN: 2442-5435)

diterbitkan oleh Ikatan Apoteker Indonesia - Sumatera Barat homepage: http://jsfkonline.org

\title{
Senyawa Antioksidan Ekstrak Metanol Glycine max (L.) Merr Varietas Detam 1 Hasil Estraksi Ultrasonik
}

\author{
(Antioxidant compounds of Methanolic Extract of Soybean (Glycine max (L) Merill) Detam 1 \\ variety from Ultrasound extraction method) \\ Rika Yulia* \& Ivon Sindu Wijaya \\ Fakultas Farmasi Universitas Surabaya
}

\begin{abstract}
Keywords: $\quad$ ABSTRACT: The objective of this study is to find antioxidant compounds which are contained Glycine max Detam 1 variety, Antioxidant compounds, Methanol extract, Ultrasonic in methanol extract of Glycine max Detam 1 variety from Ultrasound extraction method. Extraction has done by two solvents; n-hexane solvent to eliminate the soy fat which can affect the analysis result and methanol $80 \%$ to take the active compounds in soybean. The result of extraction was concentrated by using Rotary evaporator (BUCHI Rotavapor R-114) and BUCHI Water bath B-480. As the result of this study, there were three antioxidant compounds detected, i.e. Methyl-10-trans,12-cis-octadecadienoate, Methyl 9-cis,11-trans-octadecadienoate, and 9,12-Octadecadinoic acid.
\end{abstract}

Kata kunci:

Glycine max varietas

Detam 1, Senyawa antioksidan, Ekstrak metanol, Ultrasonik
ABSTRAK: Penelitian ini bertujuan untuk mengetahui kandungan senyawa antioksidan yang terkandung dalam ekstrak metanol Glycine max (L.) Merr varietas Detam 1 hasil dari ekstraksi dengan metode ultrasonik. Ekstraksi dilakukan dengan 2 pelarut yaitu pelarut n-heksan untuk menghilangkan lemak yang mungkin dapat mempengaruhi hasil selama analisis dan metanol $80 \%$ untuk mengambil senyawa aktif dalam kedelai. Hasil ekstraksi kemudian dipekatkan dengan Rotary evaporator (BUCHI Rotavapor R-114) dan BUCHI Waterbath B-480. Analisis dilakukan secara kualitatif dengan menggunakan Gas Chromatography-Mass Spectra (GS-MS). Analisis terhadap senyawa antioksidan menggunakan GC-MS menunjukkan terdapat tiga senyawa antioksidan yaitu Methyl-10-trans,12-cis-octadecadienoate, Methyl 9-cis,11-trans-octadecadienoate, dan 9,12-Octadecadinoic acid.

\section{PENDAHULUAN}

Kemampuan radikal bebas mengoksidasi zat lain (oksidator), dapat menyebabkan kerusakan oksidatif di dalam tubuh. Sebagai contoh, spesies oksigen reaktif (reactive oxygen spesies - ROS), dapat bereaksi dengan makromolekul di dalam tubuh, seperti protein, lipid, dan asam nukleat, sebagai upaya untuk memperoleh pasangan elektron sehingga tercapai kestabilan atom atau molekul. Reaksi ini merupakan reaksi rantai, berlangsung terus menerus dalam tubuh dan bila tidak dihentikan akan menimbulkan stress oksidatif. Kondisi tersebut berkontribusi terhadap timbulnya penyakit. Antioksidan, merupakan suatu substansi penting yang diperlukan oleh tubuh dalam mengatasi stress oksidatif, di mana antioksidan mampu menangkap radikal bebas tersebut
*Corresponding Author: Rika Yulia (Fakultas Farmasi Universitas Surabaya, Jalan Raya Kalirungkut, Surabaya, 60293) email: rika_y@staff.ubaya.ac.id 
sehingga tidak dapat menginduksi suatu penyakit [1,2]. Secara alamiah sel memiliki sejumlah mekanisme perlindungan terhadap kerusakan akibat radikal bebas. Respons tubuh dalam mengatasi radikal bebas seperti ROS terdiri atas beberapa mekanisme detoksifikasi, yaitu berupa sistem terintegrasi yang melibatkan molekul non-enzimatik maupun enzimatik. Molekul nonenzimatik, seperti asam askorbat, $\alpha$-tokoferol, dan glutation. Enzim yang terlibat dalam mekanisme detoksifikasi seperti katalase (CAT), glutation reduktase (GR), superoxide dismutase (SOD), polifenol oksidase (PPO), peroksidase (POX), dan lain-lain $[3,4]$.

Kebutuhan akan antioksidan sekunder, yang dapat membantu peran antioksidan enzimatis dalam tubuh sebagai preventif terjadinya stress oksidatif semakin meningkat, terutama bahan alamiah. Kedelai memiliki potensi besar untuk dikembangkan sebagai alternatif antioksidan sekunder. Kedelai merupakan komoditas yang sangat diminati dan popular di masyarakat dengan berbagai macam bentuk olahannya dan terbukti memiliki aktivitas antioksidan sebagai penangkap radikal bebas $[5,6,7]$.

Senyawa antioksidan alami pada tumbuhan umumnya adalah senyawa fenolik atau polifenolik yaitu golongan flavonoid seperti isoflavon [8]. Terdapat setidaknya tiga jenis isoflavon dalam kedelai yang terbukti berkhasiat sebagai antioksidan yaitu daidzein, glisitein, dan genistein, dimana genistein merupakan antioksidan yang paling kuat dan terbanyak konsentrasinya [9,10]. Senyawa bioaktif penting lainnya yang terdapat dalam kedelai yang berefek antioksidan yaitu asamasam lemak tidak jenuh, saponin, dan vitamin $\mathrm{E}$.

Aktivitas antioksidan kedelai Glycine max (L.) Merr dipengaruhi oleh banyak faktor, salah satunya adalah varietas. Beberapa penelitian yang membandingkan aktivitas biologis berbagai varietas biji kedelai telah dilakukan. Ekstrak
Glycine $\max$ (L.) Merr. varietas Argomulyo efektif dalam mengurangi kerusakan sel hepar mencit yang telah terintoksikasi $\mathrm{Pb}$ [11]. Terdapat variasi besarnya aktivitas antioksidan Glycine max (L.) Merr, varietas Burangrang, Ijen, Argomulyo dan Kaba [12].

Untuk mengetahui kandungan senyawa antioksidan, maka diperlukan suatu analisis. Digunakan biji kedelai hitam varietas Detam 1 yang merupakan kedelai unggulan berkualitas tinggi yang sudah diakui Badan Benih Nasional berdasarkan Surat Keputusan Menteri Pertanian November 2008 [13] karena mengandung protein lebih banyak dibandingkan jenis kedelai kuning.

\section{METODE PENELITIAN}

\section{Alat dan Bahan}

Pada penelitian ini digunakan alat-alat sebagai berikut: blender, alat-alat gelas, neraca analitik (OHAUS Pa214 dan AND GR-202) pengayak mesh 20, bejana KLT (CAMAG), sinar UV, ultrasonik bath (Ultrasonic Bronsonic 85 10E-MTH), thermometer, rotary evaporator yaitu BUCHI Rotavapor R-114, BUCHI Vacuum pump V-700, BUCHI Waterbath B-480, dan BUCHI Vacuum controller V-850, GC-MS (Shimadzu Model QP$2010 \mathrm{SE})$.

Bahan tanaman yang digunakan dalam penelitian ini adalah biji kedelai hitam (Glycine max L.) Merr varietas Detam 1 yang telah disertifikasi oleh UPBS (Unit Pengelolaan Benih Sumber) BALITKABI (Balai Penelitian Tanaman Aneka Kacang dan Umbi), Malang, Jawa Timur.

\section{Metode}

\section{Pembuatan ekstrak metanol Glycine max}

Serbuk biji kedelai 50 g, diekstraksi dengan 100ml n-heksan dengan ultrasonic bath. Hasil ekstraksi disaring dengan menggunakan kertas 
saring, sementara ampasnya diekstraksi kembali dengan n-heksan. Hasil ekstraksi pertama dan kedua kemudian digabung dan dikumpulkan dalam satu wadah. Ampas hasil ekstraksi dengan n-heksan ditambahkan pelarut yaitu metanol $80 \%$ (yang mengandung $\mathrm{HCl} 0,1 \%$ ) sebanyak $150 \mathrm{ml}$, kemudian diekstraksi menggunakan ultrasonic bath selama 10 menit dengan suhu $60^{\circ} \mathrm{C}$. Hasil ekstraksi disaring dan ampas diekstraksi kembali dengan metanol $80 \%$ pada ultrasonic bath. Hasil ekstraksi pertama dan kedua dikumpulkan dalam satu wadah. Ekstrak akan dibuat dari $400 \mathrm{~g}$ serbuk kedelai, sehingga dilakukan 8 kali proses yang sama. Keseluruhan hasil ekstraksi dikumpulkan dalam satu wadah untuk dipekatkan dengan rotary evaporator dan water bath sampai bobot konstan.

\section{Pembuatan Larutan Ekstrak Kedelai Uji}

Larutan uji dibuat dengan menimbang ekstrak kental kedelai sebanyak $\pm 60 \mathrm{mg}$ dan dilarutkan dalam 10ml metanol p.a, sehingga diperoleh konsentrasi larutan \pm 6000 bpj.

Analisis Kualitatif senyawa aktif Ekstrak Metanol Biji Kedelai Varietas Detam 1 dengan Kromatografi Gas Spektrometri Massa (KGSM)

Instrumen yang digunakan adalah GC-MS Shimadzu QP 2010 SE. Kondisi analisis pada penelitian ini yaitu menggunakan kolom Restek semipolar (Crossbond ${ }^{\circledR}$ 5\% diphenyl/95\% dimethyl polysiloxane) $60 \mathrm{~m}$ length $\mathrm{x} 0,25 \mathrm{~mm}$ ID x 0,25 $\mu \mathrm{m}$ $\mathrm{dF}$, gas pembawa helium, volume injeksi sampel $1,00 \mu \mathrm{L}$, temperatur injektor $230^{\circ} \mathrm{C}$, temperatur antarfase $250^{\circ} \mathrm{C}$, temperatur kolom $150^{\circ} \mathrm{C}$ selama 2 menit lalu ditingkatkan sampai $240^{\circ} \mathrm{C}$ sampai 10 menit, laju aliran $1,21 \mathrm{ml} /$ menit, dan waktu analisis 20 menit. Metode menggunakan energi ionisasi pada instrumen GC-MS sebesar $70 \mathrm{ev.}$

Dilakukan juga analisis dengan waktu analisis yang lebih lama yaitu 80 menit (Orhan et al., 2008) dengan kondisi analisis yaitu menggunakan kolom
Restek semipolar (Crossbond ${ }^{\circledR}$ 5\% diphenyl/95\% dimethyl polysiloxane) $60 \mathrm{~m}$ length $\mathrm{x} 0,25 \mathrm{~mm}$ ID $\mathrm{x}$ $0,25 \mu \mathrm{m} \mathrm{dF}$, gas pembawa helium, volume injeksi sampel $1,00 \mu \mathrm{L}$, temperatur injektor $230^{\circ} \mathrm{C}$, temperatur antarfase $250^{\circ} \mathrm{C}$, temperatur kolom $60^{\circ} \mathrm{C}$ selama 10 menit dinaikkan sampai $220^{\circ} \mathrm{C}$ dengan laju $4^{\circ} \mathrm{C} /$ menit dan dipertahankan selama 10 menit, dinaikkan lagi sampai temperatur akhir $240^{\circ} \mathrm{C}$ dengan laju $1^{\circ} \mathrm{C} /$ menit., laju aliran $0,8 \mathrm{ml} /$ menit, dan waktu analisis selama 80 menit.

\section{HASIL DAN DISKUSI}

Hasil pengujian organoleptis ekstrak metanol biji Glycine max varietas Detam 1 yang meliputi warna, bentuk dan bau dapat dilihat pada Tabel 1 .

Tabel 1. Hasil pengujian organoleptis ekstrak metanol biji Glycine max varietas Detam 1

\begin{tabular}{|ll|}
\hline Karakteristik & $\frac{\text { Pengujian }}{\text { Gumpalan kental (sangat keras) }}$ \\
\cline { 1 - 1 } Warna & Coklat kehitaman \\
\hline Bau & Agak merangsang \\
\hline
\end{tabular}

Profil Kromatografi Gas Spektrofotometri Massa Ekstrak Metanol Glycine max Varietas Detam 1 dengan Waktu Analisis 20 menit dan 80 menit dapat dilihat pada tabel 2 dan 3 .

Senyawa yang berefek antioksidan, pada waktu retensi 17,040 menit: Methyl-10-trans,12cis-octadecadienoate dan Methyl 9-cis,11-transoctadecadienoate yang keduanya merupakan asam linoleat terkonjugasi dan memiliki sifat penangkap radikal bebas $[14,15]$. Begitu juga dengan senyawa 9,12-Octadecadinoic acid, methyl ester merupakan ester asam linoleat yang berkhasiat sebagai antioksidan, tapi juga dilaporkan berkhasiat sebagai anti inflamasi dan anti arthritis. Namun ada literatur lain yang menyebutkan fungsi 9,12-Octadecadinoic acid, methyl ester yaitu sebagai hepatoprotektif, antihistaminik hipokolesterolemik, dan antieksemik [16]. 
Pada spektra hasil MS dengan metode dan waktu analisis 80 menit tidak terdeteksi senyawa yang berefek antioksidan dan juga tidak ditemukan senyawa yang sama seperti yang terdeteksi pada metode pertama. Database yang digunakan pada instrumen GC-MS Shimadzu QP 2010 SE yaitu NIST08s.LIB, senyawa yang tidak diberi * menggunakan database WILEY 8.LIB.

\section{KESIMPULAN}

Senyawa antioksidan dalam ekstrak metanol biji kedelai varietas Detam 1 antara lain: Methyl10-trans,12-cis-octadecadienoate, dan Methyl 9-cis,11-trans-octadecadienoate yang merupakan asam linoleat terkonjugasi, dan 9,12-Octadecadinoic acid yang merupakan ester asam linoleat.

Tabel 2. Data Senyawa Penyusun Ekstrak Metanol Glycine max Varietas Detam 1 dengan Metode dan Waktu Analisis 20 Menit

\begin{tabular}{|c|c|c|}
\hline $\begin{array}{l}\text { Waktu } \\
\text { Retensi }\end{array}$ & $\begin{array}{l}\text { Bobot } \\
\text { molekul }\end{array}$ & Senyawa sesuai Database pada Instrumen GC-MS Shimadzu QP 2010 SE \\
\hline 8.150 & $\begin{array}{l}414 \\
370 \\
156\end{array}$ & $\begin{array}{c}\text { 13A,3A-(Epoxyethano)-1H-indolizino }[8,1-\mathrm{CD}] \text { carbazol-7-ol } \\
\text { Aspidospermidin-17-ol } \\
\text { 2-Nonenoic acid }{ }^{*}\end{array}$ \\
\hline 8.250 & $\begin{array}{l}370 \\
168 \\
168\end{array}$ & $\begin{array}{l}\text { Aspidospermidin-17-ol } \\
\text { byciclo }[2,2,1] \text { Heptan-2-one } \\
\text { Cyclopentaneacetic acid }\end{array}$ \\
\hline 8.375 & $\begin{array}{l}192 \\
172 \\
186\end{array}$ & $\begin{array}{l}\text { 2,7-Anhydro-1-galacto-heptulofuranose* } \\
\text { 1,2-dihydro-8-hydroxylinalool* } \\
\text { 2-tert-butyl-5-propyl-1,3-dioxolan-4-one }\end{array}$ \\
\hline 8.480 & $\begin{array}{l}178 \\
263 \\
218\end{array}$ & $\begin{array}{l}\text { 2,5-Monomethylene-1-rhamnitol* } \\
\text { 4,5,6,7-Tetrahydroxydecyl isothiocyanate* } \\
\text { 5-Acetyl-1,3;2,4-di-O-methylene-d-arabitol* }\end{array}$ \\
\hline 8.515 & $\begin{array}{l}218 \\
172 \\
162\end{array}$ & $\begin{array}{c}\text { 2-Butanone,3,3-dimethyl-1-(methylthio)-,O- }[\text { (methylamino-carbonyl }] \text { Oxime } \\
\text { 2,2-Dimethyl-3-hexanol acetate* } \\
\text { 1,6-Dideoxy-2,4-monoethylene-d-altritol* }\end{array}$ \\
\hline 8.535 & $\begin{array}{l}254 \\
172 \\
242\end{array}$ & $\begin{array}{c}\text { 11-Tridecenyl propionate* } \\
\text { 2,2-Dimethyl-3-hexanol acetate* } \\
\text { Octanoic acid, Heptyl ester }\end{array}$ \\
\hline 8.600 & $\begin{array}{l}209 \\
269\end{array}$ & $\begin{array}{c}\text { 5-Ethyl -3-(5-nitro-furan-2-yl)-[1,2,4 }] \text { oxadiazole* } \\
\text { 1-B-d-Ribofuranosyl-3-[5-tetraazolyl]-1,2,4-triazole* }\end{array}$ \\
\hline 10.020 & $\begin{array}{l}194 \\
194 \\
194\end{array}$ & $\begin{array}{c}\text { a-D-galactopyranoside, methyl atau Methyl Hexopyranoside } \\
\text { a-D-glucopyranoside, methyl* } \\
\text { a-Methyl-D-mannopyranoside* }\end{array}$ \\
\hline 11.660 & $\begin{array}{l}194 \\
194 \\
194\end{array}$ & $\begin{array}{c}\text { Mome Inositol } \\
\text { 3-O-Methyl-d-glucose* } \\
\text { 4-O-Methylmannose* }\end{array}$ \\
\hline 17.040 & $\begin{array}{l}294 \\
294 \\
294\end{array}$ & $\begin{array}{l}\text { Methyl-10-trans, 12-cis-octadecadienoate* } \\
\text { Methyl 9-cis, 11-trans-octadecadienoate* } \\
\text { 9,12-Octadecadinoic acid, methyl ester }\end{array}$ \\
\hline
\end{tabular}

Keterangan: * Methyl-10-trans,12-cis-octadecadienoate, Methyl 9-cis,11-trans-octadecadienoate, dan 9,12-Octadecadinoic acid, methyl ester bersifat sebagai antioksidan. 
Tabel 3. Data Senyawa Penyusun Ekstrak Metanol Glycine max Varietas Detam 1 dengan Metode dan Waktu Analisis 80 Menit

\begin{tabular}{|c|c|c|}
\hline $\begin{array}{l}\text { Waktu } \\
\text { Retensi }\end{array}$ & $\begin{array}{c}\text { Bobot } \\
\text { molekul }\end{array}$ & Senyawa sesuai Database pada Instrumen GC-MS Shimadzu QP 2010 SE \\
\hline 4.270 & 44 & Carbonic acid gas $(\mathrm{CO} 2)$ \\
\hline \multirow[t]{2}{*}{4.635} & 82 & 1-Chlorofluoroethane \\
\hline & 64 & 1,1-Difluoroethylene-2,2-D2 \\
\hline \multirow[t]{2}{*}{4.735} & 82 & 1-Chlorofluoroethane \\
\hline & 62 & Isopropyl fluoride \\
\hline 5.355 & 104 & Trimetoxyborine \\
\hline \multirow[t]{2}{*}{5.600} & 118 & Ethyl-2-hydroxypropanoate atau Ethyl ester of lactic acid \\
\hline & 46 & Ethyl alcohol $(\mathrm{EtOH})$ \\
\hline \multirow[t]{2}{*}{8.590} & 102 & Acetic anhydride \\
\hline & 72 & Pyruvic aldehide \\
\hline \multirow[t]{2}{*}{30.605} & 128 & Azunamic atau Azulene (CAS) Cyclopentacycloheptene \\
\hline & 128 & Naphtaline \\
\hline \multirow[t]{2}{*}{31.265} & 128 & Naphtaline \\
\hline & 128 & Azunamic atau Azulene (CAS) Cyclopentacycloheptene \\
\hline \multirow[t]{2}{*}{32.695} & 126 & Hydroxymethylfurfurole \\
\hline & 124 & 2-Methoxy-5-methyl pyrazine \\
\hline \multirow[t]{3}{*}{46.785} & 194 & a-D-Glucopyranoside, methyl(CAS)Methyl.alpha.-D-glucopyranoside \\
\hline & 194 & a-D-Galactopyranoside, methyl(CAS)Methyl.alpha.-D-galactopyranoside \\
\hline & 178 & a-L-Galactopyranoside, methyl 6-deoxy-(CAS)Methyl.alpha.-L-fucopyranoside \\
\hline
\end{tabular}

\section{UCAPAN TERIMA KASIH}

Terimakasih kepada DIKTI yang telah mendanai penelitian ini melalui Hibah Bersaing untuk pendanaan tahun 2015.

\section{DAFTAR PUSTAKA}

1. Winarsi, Hery. (2007). Antioksidan Alami dan Radikal Bebas Potensinya dan dalam Kesehatan, Penerbit Kanisius, Yogyakarta

2. Suarsana, Wresdiyati T, Suprayogi A. (2013). Respon Stres Oksidatif dan Pemberian Isoflavon terhadap Aktivitas Enzim Superoksida Dismutase dan Peroksidasi Lipid pada Hati Tikus. JITV, 18(2).

3. Birben E, Sahiner UM, Sackesen C, et al (2012). Oxidative Stress and Antioxidant Defense. WAO Journal, 9-19.

4. Kumar S. (2011). Free Radicals and Antioxidants: Human and Food System. Adv Appl Sci Res, 2(1), 129-135

5. Astuti S. (2008). Isoflavon Kedelai dan Potensinya Sebagai Penangkap Radikal Bebas, Lampung: Jurnal Teknologi Industri dan Hasil Pertanian, 13(2)
6. Yulia R., Karina L., dan Veronica. (2014). Efek Glycine max Varietas Anjasmoro terhadap Kadar Timbal dan Malondialdehid pada Mencit Terintoksikasi Timbal. Jurnal Farmasi Indonesia, 7 (2), 27-33

7. Yulia R, Ressandy, S.S., Puspikaryani, G.A.P et al. (2014) Glycine max Detam II Variety as Preventive and Curative Organ Damage due to Exposure to Lead $(\mathrm{Pb})$. International Conference on Phamaceutics and Pharmaceutical Sciences

8. Barnes S.P. (2010). Lymphatic Research and Biology, The Biochemistry, Chemistry and Physiology of the Isoflavones in Soybeans and their Food Products

9. Ginting E, Antarlina S.S and Sri Widowati. (2009). Varietas Unggul Kedelai untuk Bahan Baku Industri Pangan. Jurnal Litbang Pertanian, 28(3)

10. Bhol, C. Sekhar. (2012). Isolation and Characterization of Soybean (Glycine max) Lectin. Tesis tidak dipublikasikan, Rourkela, National Institute of Technology Rourkela

11. Yulia R, dan Ningsih TNJ. (2015). Aktivitas Ekstrak Glycine max (L.) Merr. Varietas Argomulyo Terhadap Kadar Timbal dalam Darah dan Gambaran Histologi Hepar Mencit Yang Terintoksikasi Timbal. Prosiding LLPM Unisba 
12. Yulia R, Azminah, Michella, Andre T. (2015). An Assay of Antioxidant of Methanolic Extract Various of Soybean. Jurnal Farmasi Sains dan Klinis, 1(2), 122-131.

13. Hidayat, Meilinah, Dikdik K., et al. (2010). Perbandingan Kandungan Makronutrisi dan Isoflavon dari Kedelai Detam 1 dan Wilis serta Potensinya dalam Menurunkan Berat. Bionatura:Jurnal IImu-ilmu Hayati dan Fisik,12(1), 5-13.

14. Yu, Liangli. (2001). Free Radical Scavenging Properties of Conjugated Linoleic Acids. Journals of Agricultural and Food Chemistry, 49(7), 3452-3456.
15. Aydin, R. (2005). Conjugated linoleic acid: chemical structure, sources and biological properties. Turkish Journal of Veterinary Animal Science, 29(2), 189-195.

16. Devi, J., \& Muthu, A. K. (2014). Gas Chromatography-Mass Spectrometry Analysis of Bioactive Constituents in The Ethanolic Extract of Saccharum spontaneum Linn. International Journal of Pharmacy \& Pharmaceutical Sciences, 6(2), 755-759. 